\title{
Ovine White-Liver Disease (OWLD). Treatment trials
}

Ovine white-liver disease (OWLD) occurs in cobalt/-vitamin $B_{12}$ deficient lambs in Norway, and can be prevented by Co supplementation or regular dosing with $\mathrm{B}_{12}$ (Ulvund \& Pestalozzi 1990a, Ulvund 1990a). Lambs which developed OWLD showed early signs of liver damage (Ulvund 1990b). Serum copper was higher in OWLD lambs than in $\mathrm{Co} / \mathrm{B}_{12}$ supplemented controls and although the $\mathrm{Cu}$ content of OWLD pasture grass was scarce (Ulvund \& Pestalozzi 1990b), Cu supplementation alone worsened the condition (Ulvund 1990c). There were some indications that OWLD lambs recovered very slowly on indoor feeding. It therefore became of interest to evaluate various treatments of lambs with clinical OWLD, to explore whether the hepatic damage was persistent and irreversible, and to examine the length of convalescence when affected lambs were put on indoor feeding only. There are few earlier reports on these aspects. Some authors report clinical improvement of OWLD after $B_{12}$ treatment (Richards \& Harrison 1981, Mitchell et al. 1982).

Experiment $A$ : Three lambs with typical OWLD were treated on pasture (September 6) every second week with either $B_{12}$ (hydroxocobolamin, $2 \mathrm{mg}$, NYCO, Norway), copper oxide needles (Copporal, 2 g, Beecham Animal Health, England, $\mathrm{CuO}$ ), or both $\mathrm{B}_{12}$ and $\mathrm{CuO}$.

Experiment $B$ : Three OWLD affected lambs were treated on pasture fortnightly with $B_{12}$ (from August 9).

Experiment $C$ : Six affected lambs were put indoors (September 4) and fed hay and silage ad lib., and an individual daily ration of about $300 \mathrm{~g}$ concentrates containing $12.5 \%$ digestible crude protein, with $0.2 \mathrm{mg}$ cobalt $(\mathrm{CoO})$ and $10 \mathrm{mg}$ copper $(\mathrm{CuO})$ added per $\mathrm{kg}$ feed. Four of these were treated fortnightly with $B_{12}$, while 2 were left untreated.

Dosing of lambs on pasture with $\mathrm{B}_{12}$ (Exp. $A$ and $\mathrm{B})$, or $\mathrm{B}_{12}$ and $\mathrm{CuO}$, gave a quick clinical improvement, with $2-3 \mathrm{~kg}$ in live weight (lw) gain per week. Only the lamb dosed with $\mathrm{CuO}$ showed no improvement. The four $B_{12}$ treated lambs fed indoors (Exp. C) regained normal appetite during the first week after treatment. The eye discharge and the crusts on ears disappeared after 2-4 weeks, and weekly lw gain was 1-2 kg. The 2 untreated lambs regained their appetite after 6-8 weeks, and then started to gain weight. During 3 months, the $4 \mathrm{~B}_{12}$ treated lambs gained on average $8 \mathrm{~kg}$ more than the untreated ones.

$\mathrm{B}_{12}$ treatment (Exp. A) resulted in lowered serum $\mathrm{Cu} 1$ month later, while this effect was not seen in the lamb given both $B_{12}$ and $\mathrm{CuO}$ (Table 1). Serum $\mathrm{Cu}$ was only slightly higher in the $\mathrm{CuO}$ treated lambs than in the untreated ones. $B_{12}$ treatment in Exp. B also depressed serum $\mathrm{Cu}$, viz. from pretreatment value $14 \mu \mathrm{mol} / \mathrm{l}$ to $9 \mu \mathrm{mol} / \mathrm{l}$ about 4 weeks after first treatment. In Exp. C, mean serum $\mathrm{Cu}$ was $13 \mu \mathrm{mol} / \mathrm{l} 2$ months after treatment, as compared with $20 \mu \mathrm{mol} / \mathrm{l}$ for the undosed.

Serum iron $(\mathrm{Fe})$, glutamate dehydrogenase (GLDH), and plasma vitamin $B_{12}$ and methylmalonic acid (MMA) in lambs of Exp. A are given in Table 2. Dosing with $\mathrm{CuO}$, with or without $B_{12}$, kept Fe and GLDH elevated, 
Table 1. Experiment A. Mean serum $\mathrm{Cu}(\mu \mathrm{mol} / \mathrm{l})$ in unsupplemented lambs grazing OWLD pastures, and values in 3 individuals which were treated on September 6 with either copper oxide needles $(\mathrm{CuO}), \mathrm{CuO}$ and vitamin $\mathrm{B}_{12}$, or $\mathrm{B}_{12}$ only.

\begin{tabular}{lcrrr}
\hline & \multicolumn{4}{c}{ Dates of sampling } \\
\cline { 2 - 5 } Treatment & July 12 & Aug. 9 & Sept. 13 & Oct. 7 \\
\hline Untreated (mean) & 16 & 17 & 18 & 11 \\
$\mathrm{n}$ & 6 & 6 & 3 & 3 \\
\hline $\mathrm{CuO}$ & 12 & 13 & 18 & 15 \\
$\mathrm{CuO} \& \mathrm{~B}_{12}$ & 13 & 15 & 22 & 15 \\
$\mathrm{~B}_{12}$ & - & 18 & 16 & 4 \\
\hline
\end{tabular}

$\mathrm{n}=$ number of lambs sampled.

while $\mathrm{B}_{12}$ treatment alone reduced the values. $\mathrm{Cu}$ seemed to inhibit the restoring effect of $B_{12}$ on damaged liver cells. Plasma $\mathrm{B}_{12} / \mathrm{MMA}$ were normalized after $\mathrm{B}_{12}$ treatment, with ot without $\mathrm{CuO}$.

$\mathrm{CuO}$ treatment resulted in reduced packed cell volume (PCV) 1 month later $(28 \%)$ as compared with $\mathrm{CuO} \& \mathrm{~B}_{12}$, or $\mathrm{B}_{12}$ treatment (> $33 \%$ ). In Exp. $\mathrm{B}, \mathrm{B}_{12}$ treatment yielded increased plasma glucose, total cholesterol and urea 2 weeks later. GLDH was reduced from pretreatment range $26-72 \mathrm{U} / 1$ to $2-10$ $\mathrm{U} / \mathrm{l}$, but $\gamma$ GT remained unaltered. Seven weeks after treatment, mean serum $\mathrm{Fe}$ was lowered (from 39 to $28 \mu \mathrm{mol} / \mathrm{l}$ ). In Exp. C, $B_{12}$ treatment resulted in elevation of plasma glucose 3 days later, and GLDH was lowered $(<10 \mathrm{U} / \mathrm{l})$ after 10 days. Similar experiments have not been performed earlier in OWLD, but the quick glucose elevating effect of $\mathrm{B}_{12}$ corresponds to findings by MacPherson et al. (1976) in simple Co deficiency. The 2 untreated lambs fed indoors had low plasma glucose $(<2.8 \mathrm{mmol} / \mathrm{l})$, low tot. cholesterol $(<1.0 \mathrm{mmol} / \mathrm{l})$ and elevated GLDH ( $>30 \mathrm{U} / \mathrm{l}$ ) for 8 weeks, while $\gamma$ GT was $>40 \mathrm{U} / \mathrm{l}$ and $\mathrm{PCV}<30 \%$ for $2-3$ months.

Table 2. Experiment A. Serum iron ( $\mathrm{Fe}, \mu \mathrm{mol} / \mathrm{l})$, serum glutamate dehydrogenase (GLDH, U/L), plasma vitamin $B_{12}(\mathrm{pmol} / \mathrm{l})$ and methylmalonic acid (MMA $\left.\mu \mathrm{mol} / \mathrm{l}\right)$ in 3 lambs with OWLD, treated on September 6 with either $\mathrm{CuO}, \mathrm{CuO}$ and $\mathrm{B}_{12}$, or $\mathrm{B}_{12}$ only. Mean values for 6 (August) and 3 (September/October) untreated lambs are included.

\begin{tabular}{|c|c|c|c|c|c|c|c|c|c|c|c|c|}
\hline \multirow[b]{3}{*}{ Treatment } & \multicolumn{12}{|c|}{ Dates of sampling } \\
\hline & \multicolumn{4}{|c|}{ Aug. 9} & \multicolumn{4}{|c|}{ Sept. 13} & \multicolumn{4}{|c|}{ Oct. 7} \\
\hline & SI & GLDH & $\mathrm{B}_{12}$ & MMA & SI & GLDH & $\mathrm{B}_{12}$ & MMA & SI & GLDH & $B_{12}$ & MMA \\
\hline $\mathrm{CuO}$ & 5 & 23 & $\div$ & 156 & 42 & 69 & 66 & 208 & 47 & 46 & $\div$ & 162 \\
\hline $\mathrm{CuO} \& \mathrm{~B}_{12}$ & 41 & 73 & $\div$ & 102 & 44 & 85 & 552 & 5 & 32 & 80 & $\div$ & 4 \\
\hline $\mathrm{B}_{12}$ & 49 & 55 & $\div$ & 206 & 40 & 17 & 653 & 2 & 27 & 23 & $\div$ & 8 \\
\hline Untreated & 45 & 56 & 77 & 80 & 43 & 76 & 68 & 143 & 36 & 199 & 132 & 24 \\
\hline
\end{tabular}

$\div$ not examined 
In conclusion, $B_{12}$ treatment caused quick clinical improvement, elevation of plasma glucose after 3 days, reduction of serum GLDH after 10 days, elevation of cholesterol and urea after 2 weeks, and lowering of $\mathrm{Fe}$ and $\mathrm{Cu}$ after 1-2 months. In contrast, OWLD lambs put on indoor feeding recovered slowly, and clinical pathology was unchanged for 2 months. $\mathrm{Cu}$ treatment prevented healing of liver damage as judged by serum GLDH.

Martha J. Ulvund,

State Veterinary Research Station

for Small Ruminants,

Sandnes, Norway.

\section{References}

MacPherson A, Moon FE, Voss RC: Biochemical aspects of cobalt deficiency in sheep with special reference to vitamin status and a possible involvement in the aetiology of cerebral necrosis. Brit. vet. J. 1976, 132, 294-308.
Mitchell PJ, McOrist S, Thomas KW, McCausland $P$ : White liver disease of sheep. Aust. vet. J. 1982, 58, 181-184.

Richards RB, Harrison MR: White liver disease in lambs. Aust. vet. J. 1981, 57, 565-568.

Ulvund MJ: Ovine white-liver disease (OWLD). Vitamin $B_{12}$ and methyl malonic acid (MMA) estimations in blood. Acta vet. scand. 1990a, 31, 267-275.

Ulvund MJ: Ovine white-liver disease (OWLD). Changes in blood chemistry. Acta vet. scand. 1990b, 31, 277-286.

Ulvund MJ: Ovine white-liver disease (OWLD). Serum copper and effects of copper and selenium supplementation. Acta vet. scand. 1990c, 31, 287-295.

Ulvund MJ, Pestalozzi M: Ovine white-liver disease (OWLD) in Norway. Clinical symptoms and preventive measures. Acta vet. scand. 1990a, 31, 53-62.

Ulvund MJ, Pestalozzi M: Ovine white-liver disease (OWLD). Botanical and chemical composition of pasture grass. Acta vet. scand. 1990b, 31, 257-265.

(Received January 26, 1989; accepted October 9, 1989).

Reprints may be requested from: Martha J. Ulvund, State Veterinary Research Station for Small Ruminants, Høyland, P. O. Box 264, N-4301 Sandnes, Norway. 